\title{
Immunolocalisation of nervous necrosis virus indicates vertical transmission in hatchery produced Asian sea bass (Lates calcarifer Bloch) - A case study
}

\author{
I.S. Azad ${ }^{\mathrm{a}, *}$, K.P. Jithendran ${ }^{\mathrm{a}, 1}$, M.S. Shekhar ${ }^{\mathrm{a}, 1}$, \\ A.R. Thirunavukkarasu ${ }^{\mathrm{a}, 1}$, L.D de la Pena ${ }^{\mathrm{b}, 1}$ \\ ${ }^{a}$ Central Institute of Brackishwater Aquaculture, 75-Santhome High Road, R.A.Puram, Chennai-600 028, India \\ ${ }^{\mathrm{b}}$ SEAFDEC, Tigbauan 5021, Iloilo, Philippines
}

Received 6 September 2004; received in revised form 18 April 2005; accepted 24 April 2005

\begin{abstract}
A probable vertical mode of piscine nodavirus transmission is reported in the present investigation based on a case of nodavirus associated larval mortalities in hatchery produced Asian sea bass. Polyclonal rabbit anti-SJNNV antibodies (SGWak97) detected the viral antigens in the tissue sections from the eggs and the larvae at different time intervals from -1 to 42 days post hatch (dph). Immunopositive ovarian connective tissue associated with the oocytes along with the progressive localization of the viral antigens in the brain, spinal cord, liver, stomach and dermal musculature during the larval development indicates a probable vertical transmission of nodavirus in the Asian sea bass. The surviving larger larvae, from the batch suffering mass mortalities, produced very intense immunofluorescent positivity in the liver, stomach and dermal musculature. Results of this investigation demonstrating a possibility of vertical transmission of the nodavirus emphasize the need for screening of eggs and larvae for evolving suitable preventive and prophylactic health management strategies. (C) 2005 Elsevier B.V. All rights reserved.
\end{abstract}

Keywords: Lates calcarifer; Nodavirus; Vertical transmission; Immunofluorescence; Immunoperoxidase

\footnotetext{
* Corresponding author. Present address: Aquaculture, Fisheries and Marine Environment Department, KISR, Salmiya, Kuwait.

E-mail addresses: azadis@rediffmail.com,ciba@tn.nic.in (I.S. Azad), ciba@tn.nic.in (K.P. Jithendran), ciba@tn.nic.in (M.S. Shekhar), ciba@tn.nic.in (A.R. Thirunavukkarasu), ciba@tn.nic.in (L.D. de la Pena).

${ }^{1}$ Fax: +914424610311.
}

\section{Introduction}

Aquaculture of food fishes is on the rise the world over with the success of captive breeding and standardization of larval rearing technology. Asian sea bass (Lates calcarifer Bloch) is an important food fish in Asia. This fish species is found to be susceptible to various pathogens of parasitic, bacterial and viral origin (Wong and Leong, 1989; Anderson and

0044-8486/\$ - see front matter (C) 2005 Elsevier B.V. All rights reserved. doi:10.1016/j.aquaculture.2005.04.076 
Norton, 1991; Subhasinghe and Shariff, 1992; Soltani et al., 1996; Azad et al., 2004). Viral nerve necrosis due to the piscine nodavirus is the single most important viral fish disease that attracted the attention of fish health workers during the last decade. The virus is recorded from over 40 fish species covering different geographic locations. Since then several aspects of VNN have been reported (Yoshikoshi and Inoue, 1990; Mori et al., 1992; Comps et al., 1996; Munday and Nakai, 1997; Nishizawa et al., 1997; Castric et al., 2001; Starkey et al., 2000, 2001; Breuil et al., 2001; Johansen et al., 2003, 2004; Azad et al., 2005).

Glazebrook et al. (1990) accounted for the first report of picorna-like viruses affecting the Asian sea bass or barramundi. The association of nodavirus with the brain and retinal lesions and resultant mortalities in this species were reported by Renault et al. (1991). Comparison of nodavirus strains isolated from the barramundi and the European sea bass (Comps et al., 1994), nodavirus infection in the hatchery reared sea bass from Indonesia (Zafran et al., 1998), phylogeny and genetic characterization of nodaviruses from different geographic locations and fish species (Skliris et al., 2001) have all contributed immensely to events related to VNN in the Asian sea bass.

Investigations on the possible routes of VNN infection have yielded interesting information and many of them suggest a probable vertical transmission of the virus in various fish species (Arimoto et al., 1992; Grotmol et al., 1999; Grotmol and Totland, 2000; Breuil et al., 2002). The work of Arimoto et al. (1992) was probably the first, which aimed at detecting the nodavirus through antibody-based ELISA technique in the fertilized eggs. Grotmol and Totland (2000) showed that the nodavirus in artificially infected eggs of Atlantic halibut (Hippoglossus hippoglossus) could be inactivated through ozonation, thus preventing vertical transmission of the virus. Breuil et al. (2002) inoculated live nodavirus to the brood sea bass (Dicentrarchus labrax) and observed nodavirus-associated lesions in the brain and retinal tissue of the larvae suggesting a probable vertical transmission of VNN. However information on the sequence of events relating to the appearance of VNN leading to a clear indication on the vertical route of infection in the Asian sea bass (L. calcarifer) is scanty.
The present work was carried with an objective of investigating the probable route of nodavirus infection in hatchery produced Asian sea bass through immunohistochemistry and histopathology.

\section{Materials and methods}

\subsection{Fish}

The fish sample selected in the present study was from captive brood stock maintained in 500 ton outdoor cement tanks for the breeding programme. The brood stock was collected (2-4 years-old) from the coastal waters off Chennai, India and domesticated (5-6 years under captive conditions) at the fish hatchery of the institute. There was no known history of the VNN outbreak in the hatchery previously. Daily water exchange of $25 \%$ using filtered seawater (34-36 ppt) was carried out. Eggs from a randomly selected potential female fish were collected using a catheter. As a part of the general procedure, the brood is examined for the ripeness of the ovary by pressing the abdomen for free ova and collecting a sample of eggs using a catheter inserted into the vent leading to the ovary. The sampled eggs corresponded to, roughly, $24 \mathrm{~h}$ prehatch. The female fish was induced to spawn using hormonal induction. Fertilized eggs were hatched and reared separately, but in the hatchery environment where several batches of eggs/hatchlings are generally held. Eggs and hatchlings sampled at $-1,0,2,4,6$, $10,15,20,25$ and $42 \mathrm{dph}$ were fixed in $10 \%$ buffered formalin and processed for histology. Mass mortality of the hatchlings was observed at 18-21 dph with typical clinical manifestations of viral nervous necrosis such as anorexia, blackening, lack of swimming coordination and settling to bottom. Paraffin embedded sections of eggs and larvae were used for standard histological staining (haemotoxylin and eosin; H\&E) and immuno-staining (immunoperoxidase and immunofluorescence). Moribund larvae were tested positive by RT-PCR for the presence of the piscine nodavirus (Azad et al., 2005).

\subsection{Light microscopy}

Paraffin embedded tissue sections of eggs and whole larvae, sampled at different time intervals, 
were stained using $H \& E$ and gross pathological features were recorded and documented as microphotographs. Portions of sections were selected in such a way that three consecutive sections, normal (H\&E), immunostained (immunoperoxidase/immunofluorescence) and control were available for comparison. Sections from each tissue were incubated with the normal rabbit serum instead of SJNNV specific (SGWak97) rabbit antibodies to serve as controls. Samples of larvae collected were grouped into 3 categories as: pre-clinical manifestation phase (up to $10 \mathrm{dph}$ ), phase of onset of clinical manifestations (10$18 \mathrm{dph}$ ) and phase of morbidity or mortality (19-23 $\mathrm{dph}$ ) for the purposes of interpretation of observations made on the histopathological manifestations in the brain, spinal cord and other tissues.

\subsection{Immunostaining}

Paraffin sections were deparaffinised in xylene and hydrated through graded levels of alcohol to distilled water. The sections selected for immunoperoxidase were treated with $\mathrm{H}_{2} \mathrm{O}_{2} /$ methanol $(0.02 \% \mathrm{v} / \mathrm{v})$ during rehydration process for blocking the endogenous peroxidase of the tissue. Hydrated sections were used in both the cases of immunoperoxidase and immunofluorescence. Briefly, the sections were treated with trypsin $(0.1 \% \mathrm{w} / \mathrm{v}$ in phosphate buffered saline, PBS, biochemical grade, Hi Media, India) for 10 min and washed twice with PBS-Tween 20 (T-20, Hi Media, India; $0.01 \% \mathrm{v} / \mathrm{v}$ with PBS). Non-specific antibody binding sites were blocked for 30 min using $3 \%$ bovine serum albumin (in PBS, $\mathrm{pH}$ 7.4) and washed with PBST. The sections were treated with the first antibody (rabbit anti-SJNNV SGWak97, SEAFDEC, Philippines) at a dilution of 1:50 (sterile PBS, $\mathrm{pH}$ 7.4) for $1 \mathrm{~h}$ in a humid chamber, while the control sections were incubated with normal unimmunised rabbit serum of identical dilution. Sections were washed with PBST before treating with goat anti-rabbit HRP conjugate or goat anti rabbit-FITC conjugate for $1 \mathrm{~h}$ depending on the nature of immunostaining. The sections were again washed with PBST. Alcohol insoluble chromogen (di amino benzidene, DAB) was used on immunoperoxidase sections for $10 \mathrm{~min}$ and washed with PBST. The sections treated with goat anti rabbit FITC conjugate were washed before lightly blotting and mounting using glycerol. All immunochemicals were procured from Bangalore Genei Pvt. Ltd., India unless specified.

The sections for immunoperoxidase were background stained using haematoxylin, blued in $0.5 \%$ liquid ammonia and dehydrated through graded levels of alcohol. The sections were xylene cleared and mounted using DPX. Observations were recorded using Leica microscope and Nikon digital camera. The localization pattern was graded based on the intensity of immunostaining as; negative $(-)$, weak $(-/+)$, mild $(+)$, strong $(++)$ and very strong $(+++)$ immunopositivity.

\section{Results}

Light microscopy of the eggs and larvae, in the present study, did not show any signs of pathological manifestations typical of VNN till $15 \mathrm{dph}$. However, clear vacuolative nerve necrosis was evident in the sections of nerve tissue of the larvae from $15 \mathrm{dph}$ (Fig. 1). The spinal cord in the pre-clinical manifestation phase showed darkly stained and actively dividing neuronal zone without vacuolation (Fig. 1a). However, as the disease progressed, vacuolated nerve cells of the spinal cord, containing viral inclusions in their cytoplasm, were noticed (Fig. 1b). The neuronal tissue, of both spinal cord (Fig. 1c and d) and the brain (Fig. 1e and f) showed viral inclusions in the cytoplasm with emarginated and pyknotic nuclei in the second phase showing clinical manifestation. Highly vacuolated spinal cord and brain tissue (Fig. $1 \mathrm{~g}$ and h), typical of VNN, were the characteristic histological features of the moribund and dead fish larvae.

Immunoperoxidase and immunofluorescence of the eggs and tissue samples from the larvae at different stages of development is depicted in Fig. 2a to i. The sections were graded based on the intensity of positive staining. Localization pattern of the nodaviral antigens is given in Table 1. Both, immunofluorescence and immunoperoxidase revealed clear nodavirus localization in the stroma of the connective tissue covering the oocytes (Fig. 2 a and b, respectively). The brain of the larvae up to $6 \mathrm{dph}$ showed negative immunostaining. Weak immunofluorescence was observed in the brain of the larvae sampled at 6 $\mathrm{dph}$. It was interesting to note that the musculature of the larvae showed weak immunofluorescence at 4 

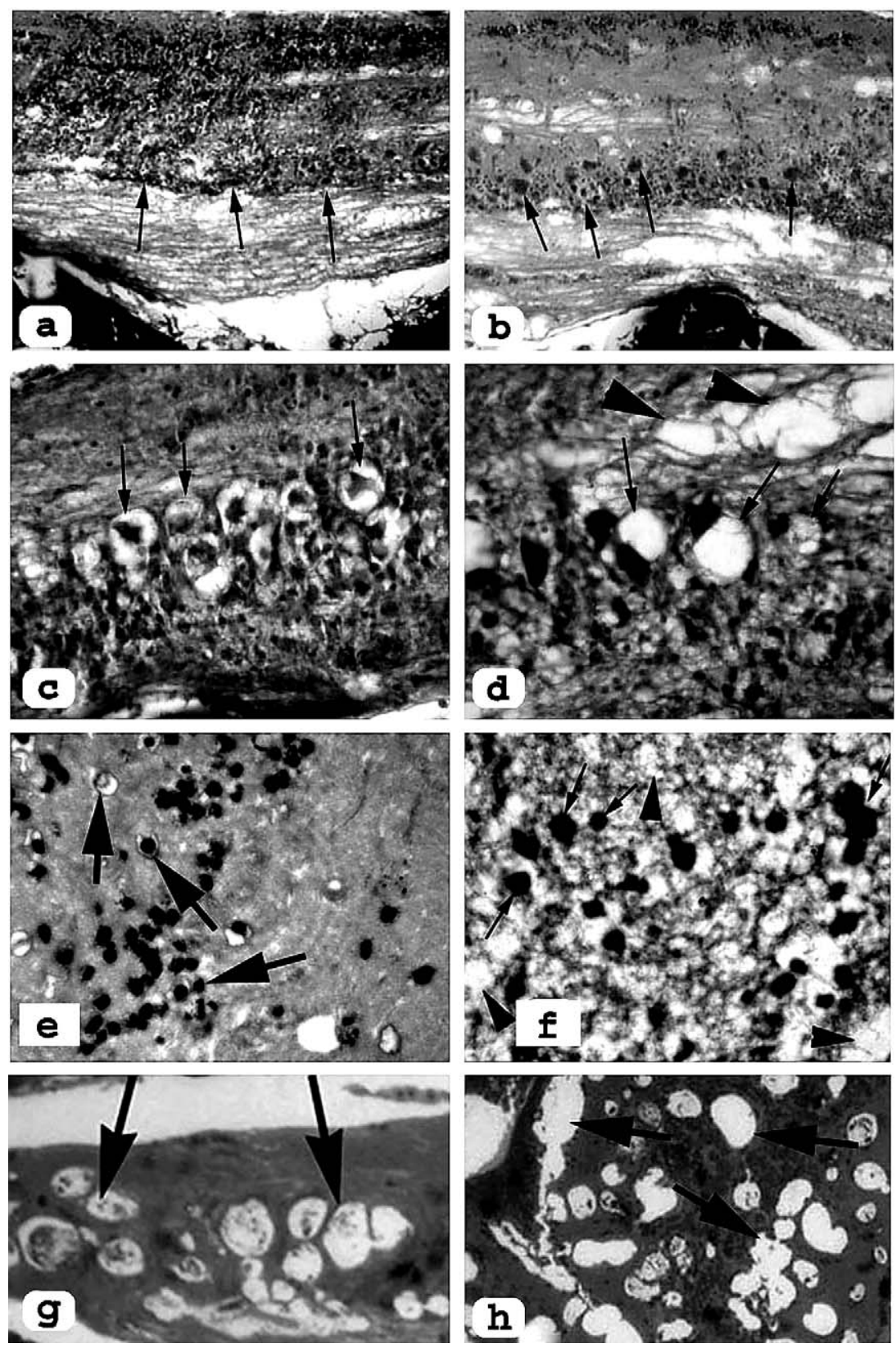

Fig. 1. a. Section of spinal cord from pre-clinical Asian sea bass larvae (10-15 dph) with darkly stained neuronal zone and indications of the onset of nerve cell necrosis (arrows). H\&E, 400×. b. Advanced pre-clinical stage of the spinal cord, viral inclusions in the cytoplasm of the nerve cells clearly discernible (arrows). H\&E. 100×. c. Spinal cord with viral inclusion bodies in nerve cells (arrows) during the clinical manifestation stage. H\&E, 400×. d. Spinal cord with prominent vacuolation of the nerve cells (arrow heads) and emarginated nuclei. The nerve cells show intracytoplasmic viral inclusion bodies in the clinical manifestation stage. H\&E, 400×. e. The nerve cells of the brain show intracytoplasmic viral inclusion bodies (arrows) during the clinical manifestation stage. H\&E, 400×. f. Brain nerve cell vacuolation (arrow heads) and hypertrophied/pyknotic nucleii (arrows) in the clinical manifestation stage. H\&E, 400×.g and h. Gross vacuolated pathology of the spinal cord $(1 \mathrm{~g})$ and brain $(1 \mathrm{~h})$ in the moribund/dead larvae. H\&E, 400×. 

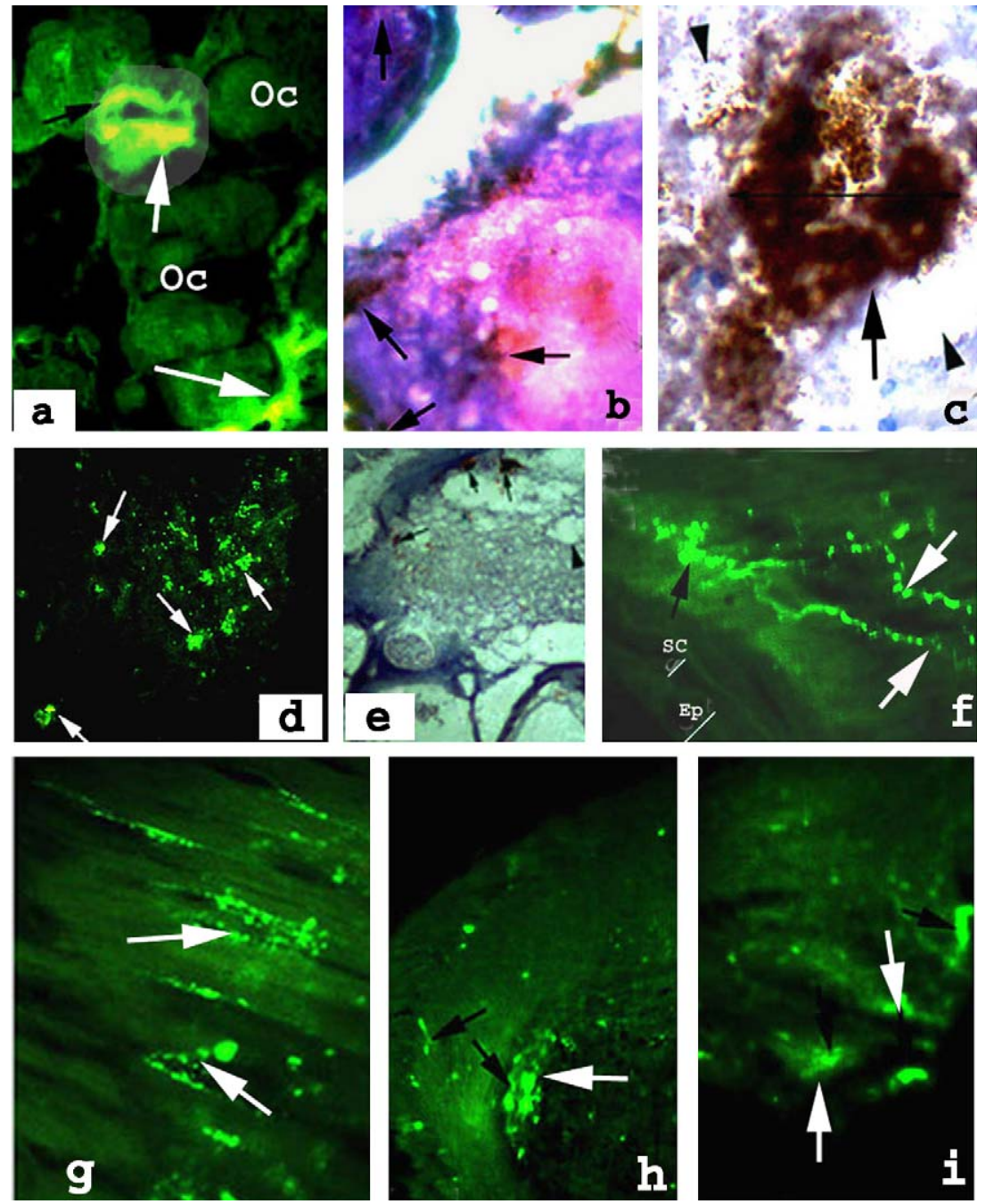

Fig. 2. a. NNV specific immunofluorescence is seen in the released oocytes (pre-spawning) of Asian sea bass. Stroma of connective tissue of the oocytes (Oc) shows strong immunofluorescence indicating the presence of NNV. $100 \mathrm{x}$. b. Immunoperoxidase stained oocytes of Asian sea bass with clear localization of NNV in ovarian tissue. $400 \times$. c. Immunoperoxidase stained brain tissue of the Asian sea bass sampled at $10 \mathrm{dph}$ showing strong localization of NNV (arrow). Note the vacuolation of the nerve cells (arrow heads). 400×. d. Immunofluorescent localization of NNV (arrows) in the brain of sea bass larvae sampled at $10 \mathrm{dph} .400 \times$. e. Weak immunoperoxidase localization of NNV (arrows) in spinal cord of the moribund larvae shows severe necrotic nerve cells (arrow heads). $100 \times$. $\mathrm{f}-\mathrm{i}$. Sections of skeletal musculature (2f and g) stomach $(2 \mathrm{~h})$ and liver (2i) of the surviving Asian sea bass larvae show NNV specific immunofluorescence. Note the proximity of the scale (SC) pockets and the epithelium (Ep) to a strongly NNV-localised skeletal musculature (2f) and intramuscular localization (arrows) in the surviving larvae (2g).

dph and a convincing localization at $6 \mathrm{dph}$, before a positive localization in the brain. Strong immunoperoxidase reactivity was noticed in the brain of the larvae at 18-20 dph (Fig. 2c). Prominent immunofluorescence covering most part of the brain was noticed in the sections of the brain sampled on 10 to $20 \mathrm{dph}$ (Fig. 2d) that corresponded with the onset of clinical manifestations of VNN followed by mortalities. Again, weak immunoperoxidase activity was noticed in the nerve tissue and clear vacuolative degeneration of the spinal cord at 40 dph (Fig. 2e) in surviving larvae. In these larvae very intense immunofluorescence of the musculature underlying the cuticular epidermis was noticed (Fig. $2 \mathrm{f}$ and $\mathrm{g}$ ). Strong viral 
Table 1

Immunolocalisation of nerve necrosis virus in the eggs and larvae of Asian sea bass from 0 to $42 \mathrm{dph}$

\begin{tabular}{lllllllllll}
\hline Tissue & \multicolumn{10}{l}{ Time (days post hatch) } \\
\cline { 2 - 9 } & -1 & 0 & 2 & 4 & 6 & 10 & 15 & 20 & 25 & 42 \\
\hline Eggs & +++ & $\mathrm{Na}$ & $\mathrm{Na}$ & $\mathrm{Na}$ & $\mathrm{Na}$ & $\mathrm{Na}$ & $\mathrm{Na}$ & $\mathrm{Na}$ & $\mathrm{Na}$ & $\mathrm{Na}$ \\
Brain & $\mathrm{Na}$ & - & - & - & $-/+$ & ++ & ++ & +++ & +++ & + \\
Spinal cord & $\mathrm{Na}$ & - & - & - & $-/+$ & ++ & ++ & ++ & +++ & ++ \\
Eye & $\mathrm{Na}$ & - & - & - & - & $-/+$ & + & + & ++ & ++ \\
Liver & $\mathrm{Na}$ & - & - & - & - & - & $-/+$ & $-/+$ & ++ & ++ \\
Spleen & $\mathrm{Na}$ & - & - & - & - & $-/+$ & $-/+$ & ++ & ++ & ++ \\
Kidney & $\mathrm{Na}$ & - & - & - & - & - & - & $-/+$ & + & ++ \\
Stomach & $\mathrm{Na}$ & - & - & - & - & - & $-/+$ & + & ++ & ++ \\
Musculature & $\mathrm{Na}$ & - & - & $-/+$ & + & + & + & ++ & +++ & +++ \\
\hline
\end{tabular}

Na not applicable; - negative; $-/+$ weak or doubtful; + mild; ++ strong; +++ very strong.

localization in the musculature in close proximity of the scale pockets and the epithelium can be noticed in the surviving larvae. Stroma of the stomach (Fig. 2h) and liver (Fig. 2i) musculature also showed the presence of the viral antigens. No specific immunostaining was noticed in the control sections of fish tissues or oocytes. The pattern of tissue localization of nodavirus infers that the neuronal tissue was strongly immunopositive to VNN during the clinical manifestation and morbidity phases of disease development while, localization in other tissues such as liver, stomach musculature and the skeletal musculature was noticed in the surviving larvae.

\section{Discussion}

Histopathology has been the most consistent indicator of nodavirus infection. Vacuolative necrosis of the nerve tissue has been the single most important histopathological diagnostic feature. Immunopositive staining of the connective tissue associated with the oocytes of the Asian sea bass, in this study, showed the possibility of the nodavirus transmission through the contaminated connective tissue covering the oocytes. It is interesting to note that the conditions of handling of the female fish, for assessing the status of maturity prior to induction of spawning, provide ample scope for the loose connective tissue around the ripe oocytes to find its way in to the hatching environment. Probably this is the reason why the catheteraided egg sampling drawn prior to induced spawning contained connective tissue. The virus-containing connective tissue, thus, could have contributed to the transfection of newly hatched larvae as evidenced through positive amplification of the viral coat protein gene by RT-PCR at 20 dph (Azad et al., 2005). Immunostaining has an advantage over RT-PCR in that it facilitates in localization of the antigens in different tissues. The observations of Grotmol and Totland (2000) support the present findings of egg surface-associated nodavirus antigen localization. They showed that the infected fertilized eggs when treated with ozone did not produce nodavirus infections in the larvae inferring a probable superficial localization of nodavirus on the eggs of Atlantic halibut. Mushiake et al. (1994) reported on the vertical transmission of VNN in striped jack. More recently, Breuil et al. (2002) showed the possibility of vertical transmission of nodavirus infection in sea bass (Dicentrarchus labrax). They observed that the exposure of eggs to NNV through hatching media, diluted with cell culture supernatant containing Sb1and Sb2 (two NNV strains), resulted in ELISA positivity in the larvae at 5 and $8 \mathrm{dph}$, respectively. However, the lesion associated with the brain and retinal tissue was observed at 14-22 dph. These observations are similar to what we have reported here. Early immunopositive staining of the musculature at $4 \mathrm{dph}$ followed by the positive localization in the brain of the larvae at $6 \mathrm{dph}$, in the present study, probably indicates that the virus enters through musculature into the nerve cells.

During the hatching and subsequent stages of larval development, the ovarian tissue could have probably contributed to the infection of the larvae and hence immunopositivity of the dermal epithelium and musculature was noticed, ahead of the neuronal immuno-positivity in the present study. Negative localization of the nodavirus in the brain tissue during the early phases of development indicates that the virus is not available in quantities sufficient enough to be detected through immunohistochemistry. Similar views have been expressed by Grotmol et al. (1999). In this context, working on acute and persistent nodavirus infection in spotted wolffish, Johansen et al. (2004) have opined that neuronal cells must reach a certain level of development before they become susceptible or before any number of viruses are detectable by immunohistochemistry. 
It is also interesting to note that the nodavirus was not detectable by immunohistochemistry till the 3 weeks post-bath challenge in spotted wolffish (Johansen et al., 2003). It was suggested that the nodavirus is transmitted along nerves (Nguyen et al., 1996). The authors have suggested that the virus enters the medial spinal cord through afferent nerves in the skin and that the infection spreads from there, anteriorly to the brain and retina and posteriorly in the spinal cord. Hence, it is suggestive that the network of the lateral sensory system might have become the portal for the entry of the nodavirus in the Asian sea bass as evidenced by the immunopositive localization of VNN antigen in the musculature ahead of neuronal tissue of brain or retina.

The clinically manifested larvae in the present study showed intense localization of nodavirus in the neuronal cells of the brain and the spinal cord. It is an established observation that the severely infected larvae of several marine fish exhibit extensive vacuolative degeneration of the brain and retinal cells (Maeno et al., 2002; Oh et al., 2002; Johansen et al., 2004; Azad et al., 2005).

Intracytoplasmic vacuolation followed by nuclear degeneration were the characteristic histological manifestations in Asian sea bass at the stage of morbidity. Fluorescent antibody-based detection in cultured juveniles of seven band grouper nervous necrosis virus was reported (Tanaka et al., 2003) which emphasized the localization pattern of the SJNNV in the brain, spinal cords and retinal tissue at the severely infected stages. Similar immunolocalisation of NNV and NNVassociated histopathological manifestations were observed in many fish species (Lai et al., 2001a,b; Le Breton et al., 1997; Johansen et al., 2004).

Nodavirus localization was also noticed in other tissues such as kidney, liver, stomach and spleen of Asian sea bass larvae surviving after the VNN outbreak. Chi and co-workers have reported the presence of nodavirus in the Asian sea bass juvenile survivors after the outbreak of VNN in the larval stages (Chi et al., 2003). Though histological manifestations such as vacuolation were noticed in the liver of Atlantic halibut, the investigations did not produce conclusive immunopositive staining of this tissue. However, present investigation has revealed immunopositive localization of nodavirus in liver and other internal organs.
These observations along with the immunopositive localization of nodavirus in the connective tissue of the released oocytes suggest a possible vertical transmission of nodavirus to the newly hatched Asian sea bass larvae. It is, however, to be ascertained whether the oocytes per se or the tissue associated with the oocytes is the source of infection in the larval stages. Another interesting feature of the present findings is the proximity of the viral localization in musculature to the scale pockets and skin suggesting a possible escape route of the viral particles and thus infecting the healthy or co-habited fish. The findings of the investigations emphasize the need to screen the broodstock of Asian sea bass for producing disease-free larvae and in formulating suitable preventive husbandry practices during and after hatchery operations.

\section{Acknowledgements}

We are highly thankful to Dr. T. Nakai, Hiroshima University, Japan for kindly providing the rabbit antiSJNNV (SGWak97) antibodies for the immunohistochemistry work. We express our sincere gratitude to Dr. P. Ravichandran, Director, Dr. Mathew Abraham, Principal Scientist and in-charge Fish Culture Division, and Dr. T.C.Santiago, Principal Scientist and incharge of Aquatic Animal Health Management Section for encouragement and guidance. We thank Mr. Subburaj and Mr. Thiagaraj, for extending help in the collection and preservation of the larvae.

\section{References}

Anderson, I.G., Norton, J.H., 1991. Diseases of barramundi in aquaculture. Australian Aquaculture 5, 21-24.

Arimoto, M., Mushiake, K., Mizuta, Y., Nakai, T., Muroga, K., Furusawa, I., 1992. Detection of striped jack nervous necrosis virus (SJNNV) by enzyme-linked-immuno-sorbant-assay (ELISA). Fish Pathol. 27, 191-195.

Azad, I.S., Thirunavukkarasu, A.R., Kailasam, M., Rajan, J.J.S., 2004. Virulence and histopathology of Vibrio anguillarum like (VAL) bacterium isolated from hatchery produced juveniles of Lates calcarifer (Bloch). Asian Fish. Sci. 17, 101-110.

Azad, I.S., Shekhar, M.S., Thirunavukkarasu, A.R., Poornima, M., Kailasam, M., Rajan, J.J.S., Ali, S.A., Mathew Abraham, S.A., Ravichandran, P., 2005. Nodavirus infection causes mass mortalities in hatchery produced larvae of Asian sea- 
bass, Lates calcarifer: first report from India. Dis. Aquat. Org. 63, 113-118.

Breuil, G., Mouchel, O., Fauvel, C., Pepin, J.F., 2001. Seabass Dicentrarchus labrax nervous necrosis virus isolates with distinct pathogenicity to seabass larvae. Dis. Aquat. Org. 45, $25-31$.

Breuil, G., Pepin, J.F.P., Boscher, S., Thiery, R., 2002. Experimental vertical transmission of nodavius from broodfish to eggs and larvae of the sea bass, Dicentrarchus labrax (L.). J. Fish Dis. 25, $697-702$.

Castric, J., Thiéry, R., Jeffory, J., de Kinkelin, P., Raymond, J.C., 2001. Sea bream Sparus aurata, an asymptomatic contagious fish host for nodavirus. Dis. Aquat. Org. 47, 33-38.

Chi, S.C., Shieh, J.R., Lin, S.J., 2003. Genetic and antigenic analysis of betanodaviruses isolated from aquatic organisms in Taiwan. Dis. Aquat. Org. 55, 221-228.

Comps, M., Pepin, J.F., Bonami, J.R., 1994. Purification and characterization of two encephalitis viruses (FEV) infecting Laes calcarifer and Dicentrarchus labrax. Aquaculture 123, $1-10$.

Comps, M., Trindadem, M., Delsert, C., 1996. Investigations of fish encephalitis virus (FEV) expression in marine fishes using DIGlabelled probes. Aqauculture 143, 113-121.

Glazebrook, J.S., Heasman, M.P., de Beer, S.W., 1990. Picorna-like viral particles associated with mass mortalities in larval barramundi, Lates calcarifer Bloch. J. Fish Dis. 13, 245-249.

Grotmol, S., Totland, G.K., 2000. Surface disinfection of Atlantic halibut, Hippoglossus hippoglossus, eggs with ozonated seawater inactivates nodavirus and increases survival of the larvae. Dis. Aquat. Org. 39, 86-89.

Grotmol, S., Bergh, O., Totland, G.K., 1999. Transmission of viral encephalopathy and retinopathy (VER) to yolk-sac larvae of the Atlantic halibut Hippoglossus hippoglossus: occurrence of nodavirus in various organs and a possible route of infection. Dis. Aquat. Org. 36, 95-106.

Johansen, R., Amundsen, A., Dannevig, B.H., Sommer, A.I., 2003. Acute and persistent nodavirus infection in spotted wolfish Anarhinchas minor. Dis. Aquat. Org. 57, 35-41.

Johansen, R., Grove, S., Svendsen, A.K., Modahl, I., Dannevig, B., 2004. A sequential study of pathological findings in Atlantic halibut, Hippoglossus hippoglossus (L.), throughout one year after an acute outbreak of viral encephalopathy and retinopathy. J. Fish Dis. 27, 327-341.

Lai, Y.S., Chiu, H.C., Murali, S., Guo, I.C., Chen, S.C., Fang, K., Chang, C.Y., 2001a. In vitro neutralization by monoclonal antibodies against yellow grouper nerve necrosis virus (YGNNV) immunolocalization of virus infection in yellow grouper, Epinephelus awoara (Temminck\&Schlegel). J. Fish Dis. 24, 237-244.

Lai, Y.S., Murali, S., Chiu, H.C., Ju, HY., Lin, Y.S., Chen, S.C., Guo, I.C., Fang, K., Chang, C.Y., 2001b. Propagation of yellow grouper nervous necrosis virus in a new nodavirus susceptible cell line from yellow grouper, Epinephelus awoara (Temmink\&Schlegel), brain tissue. J. Fish Dis. 24, 299-309.

Le Breton, A., Grisez, L., Sweetman, J., Ollevier, F., 1997. Viral nervous necrosis (VNN) associated with mass mortalities in cage-reared sea bass, Dicentrarchus labrax (L.). J. Fish Dis. 20, 145-151.

Maeno, Y., de la Pena, L.D., Cruz-Lacierda, E.R., 2002. Nodavirus infection in hatchery-reared orange-spotted grouper Epinephelus coioides: first record of viral nervous necrosis in the Philippines. Fish Pathol. 37, 87-89.

Mori, K., Nakai, T., Muroga, K., Arimoto, M., Mushiake, K., Furusawa, I., 1992. Properties of a new virus belonging to Nodaviridae found in larval striped jack (Pseudocaranx dentex) with nervous necrosis. Virology 187, 368-371.

Munday, B.L., Nakai, T., 1997. Special topic review: nodaviruses as pathogens in larval and juvenile marine finfish. World J. Microbiol. Biotechnol. 13, 375-381.

Mushiake, K., Nishizawa, T., Nakai, T., Furusawa, I., Muroga, K., 1994. Control of VNN in striped jack-selection of spawners based on the detection of SJNNV gene by polymerase chainreaction (PCR). Fish Pathol. 29, 177-182.

Nguyen, H.D., Nakai, T., Muroga, K., 1996. Progression of striped jack nervous necrosis virus (SJNNV) infection in naturally and experimentally infected striped jack Pseudocaranx dentex larvae. Dis. Aquat. Org. 24, 99-105.

Nishizawa, T., Furuhashi, M., Nagai, T., Nakai, T., Muroga, K., 1997. Genomic classification of fish nodaviruses by molecular phylogenetic analysis of the coat protein gene. Appl. Environ. Microbiol. 63, 1633-1636.

Oh, M.J., Jung, S.J., Kim, S.R., Rajendran, K.V., Kim, Y.J., Choi, T.J., Kim, H.R., Kim, J.D., 2002. A fish nodavirus associated with mass mortality in hatchery-reared red drum, Sciaenops ocellatus. Aquaculture 211, 1-7.

Renault, T., Haffner, P., Laurencin, F.B., Breuil, G., Bonami, J.R., 1991. Mass mortality in hatchery reared sea bass (Lates calcarifer) larvae associated with the presence in the brain and retina of virus-like particles. Bull. Eur. Assoc. Fish Pathol. 11, $68-73$.

Skliris, G.P., Krondiris, J.V., Sinderis, D.C., Shinn, A.P., Starkey, W.G., Richards, R.H., 2001. Phylogenetic and antigenic characterization of new fish nodavirus isolates from Europe and Asia. Virus Res. 75, 59-67.

Soltani, M., Munday, B.L., Burke, C.M., 1996. The relative susceptibility of fish to infections by Flexibacter columnaris maritimus. Aquaculture 140, 259-264.

Starkey, W.G., Ireland, J.H., Muir, K.F., Shinn, A.P., Richards, R.H., Ferguson, H.W., 2000. Isolation of nodavirus from Scottish farmed halibut, Hippoglossus hippoglossus (L.). J. Fish Dis. $23,419-422$.

Starkey, W.G., Ireland, J.H., Muir, K.F., Jenkins, M.E., Roy, W.J., Richards, R.H., Ferguson, H.W., 2001. Nodavirus infection in Atlantic cod and Dover sole in the UK. Vet. Rec. 149, 179-181.

Subhasinghe, R.P., Shariff, M., 1992. Multiple bacteriosis, with special reference to spoilage bacterium Shewanell putrefaciens, in cage culture barramundi in Malaysia. J. Aquat. Anim. Health 4, 309-311.

Tanaka, S., Kuriyama, I., Nakai, T., Miyazaki, T., 2003. Susceptibility of cultured juveniles of several marine fish to the sevenband grouper nervous necrosis virus. J. Fish Dis. 26, $109-115$. 
Wong, S.Y., Leong, T.S., 1989. A comparative study of Vibrio infections in healthy and diseases marine finfishes cultured in floating cages near Penang. Malaysia. Spl. Issue. Asian Fish. Sci. 3, 353-359.

Yoshikoshi, K., Inoue, K., 1990. Viral nerve necrosis in hatchery-reared larvae and juveniles of Japanese parrotfish,
Oplegnathus fasciatus (Temmink\&Schlegel). J. Fish Dis. 13, 69-77.

Zafran, Harada, T., Koesharyani, I., Yuasa, K., Hatai, K., 1998. Indonesian hatchery reared seabass larvae (Lates calcarifer), associated with viral nervous necrosis (VNN). Indonesian Fish. Res. J. IV, 19-22. 